\title{
Evaluation of European Cranberrybush (Viburnum opulus L.) genotypes for agro-morphological, biochemical and bioactive characteristics in Turkey
}

\author{
Nilda Ersoy ${ }^{l}$, Sezai Ercisli ${ }^{2 *}$, Muttalip Gundogdu ${ }^{3}$ \\ ${ }^{1}$ Vocational School of Technical Sciences \\ Akdeniz University, Antalya, Turkey \\ ${ }^{2}$ Department of Horticulture \\ Agricultural Faculty, Atatürk University, Erzurum, Turkey \\ ${ }^{3}$ Department of Horticulture
}

Agricultural and Natural Science Faculty, Abant Izzet Baysal University, Bolu, Turkey

\begin{abstract}
The study evaluated some agro-morphological (fruit weight, fruit flesh ratio, fruit skin colour, number of fruits per raceme, number of racemes per bush), biochemical (vitamin C, soluble solids content, organic acids), and bioactive (total phenolics, total anthocyanins, total flavonoids, and antioxidant capacity) characteristics of the fruit of a number of selected European Cranberrybush (Viburnum opulus L.) genotypes grown in the Sivas province of Turkey. To evaluate the antioxidant capacity, ferric reducing antioxidant power (FRAP) assays were performed. The results showed genotype-specific differences in most of the agro-morphological, biochemical and bioactive characteristics. The range of fruit weight, number of fruits per raceme, and number of racemes per bush was between 0.67 and $0.82 \mathrm{~g}, 40.7$ and 57.1, and 470 and 581, respectively. The highest vitamin $\mathrm{C}$ and soluble solids contents were found in the fruits of genotypes SIV-9 and SIV-6 as $39 \mathrm{mg}$ per $100 \mathrm{~g}$ and $12.6 \%$, respectively. Tartaric acid was the main organic acid in all the genotypes; it ranged from 120 to $144 \mathrm{mg}$ per $100 \mathrm{~g}$ of fruit FW. Total phenolic, total anthocyanin and total flavonoid contents ranged from 621 to $987 \mathrm{mg}$ gallic acid equivalents per $100 \mathrm{~g}, 15$ to $51 \mathrm{mg}$ cyanidin-3-rutinoside equivalents per $100 \mathrm{~g}$, and 202 to $318 \mathrm{mg}$ rutin equivalents per $100 \mathrm{~g}$, respectively. Genotype SIV-10 had the highest antioxidant capacity (34.90 $\mu \mathrm{mol}$ Trolox per g, based on FRAP assays). The present study shows the potential of the evaluated European Cranberrybush genotypes for improving the nutritional value through germplasm enhancement programmes.
\end{abstract}

Key words: anthocyanins, European Cranberrybush, phenolics, flavonoids, vitamin C

\section{INTRODUCTION}

Fruits are genetically a very diverse group and are used by people for food, either as edible products or as culinary ingredients, and also for medicinal use. Because of their unique nutrient profile, wild edible fruits in particular play a more important role in human health and nutrition as better sources of vitamins, minerals, antioxidants, dietary fibre and phytonutrients (plant-derived micronutrients), which help the human body to be fit, rejuvenate, and stay free of diseases (Mikulic-Petkovsek et al. 2014, Canan et al. 2016, Zorenc et al. 2016). The levels of bioactive compounds vary between fruit

\footnotetext{
*Corresponding author.

Tel.: +90 4422311003; fax: +90 4422311014;

e-mail: sercisli@gmail.com (S. Ercisli).
} 
species, genotypes, accessions, and also between different environmental conditions (temperature, soil, water, etc.) (Mikulic-Petkovsek et al. 2015, Saridas et al. 2016, Yazici and Sahin 2016, MikulicPetkovsek et al. 2017)

Wild edible fruits show a rich biodiversity, which forms the basis for human survival and economic well-being, and constitutes the resources upon which families, communities, nations and future generations depend (Singh et al. 1994). They are harvested from forests and marginal lands of rural areas without commercial cultivation. They represent cheap but quality nutrition for large segments of the population in both urban and rural areas (Dansi et al. 2008). Most of the wild edible fruits have also medicinal properties (Ercisli et al. 2010, Mikulic-Petkovsek et al. 2012, Rop et al. 2014). Several diverse raw or processed products could be obtained from wild edible fruits, which may support household subsistence and also generate income, in particular for people living in rural areas. This situation has been a prompt to investigate those valuable plants (Mahapatra et al. 2005, Bharucha and Pretty 2010).

In Turkey, wild edible fruits are common and used by rural people, contributing significantly to their livelihood, but many of those fruits are still unknown or insufficiently exploited in Turkey despite their nutritional value (Ercisli et al. 2010).

The European Cranberrybush (Viburnum opulus L., common name: guelder-rose) is native to Europe, northern Africa and central Asia (Cesoniene and Daubaras 2006, Cesoniene et al. 2008), and is commonly found in Anatolia as wild populations. In Anatolia, Viburnum opulus fruits are called gilaburu and have been used in Turkish folk medicine for several purposes, for example, as an antidiabetic agent (Altun et al. 2008).

The European Cranberrybush grows wild in the central, western and northern provinces of Turkey, showing a rich plant diversity. The European Cranberrybush shrub, whose fruit resembles grapes and usually has 34-54 red-coloured berries, was given the name of 'Rose Ebru' during the Seljuk and Ottoman times because of its beauty when flowering (Kalyoncu et al. 2013). Red-coloured berries of the European Cranberrybush are quite rich in bioactive substances. The juice of the fruit, which matures in autumn and has its own unique taste and aroma, has diuretic effects, which means it helps to reduce body swelling and oedema, and stimulates the kidneys to remove waste materials from the body, and it can also be an important dietary fruit due to its bioactive compounds (Iwai et al. 2004, Fukuyama et al. 2005, Kim et al. 2005, Lavigne et al. 2008, Bae et al. 2010).

Although there have been some detailed reports on the morphological, bioactive and biochemical characteristics of European Cranberrybush grown in different parts of the world, there have been very few studies in Turkey regarding the European Cranberrybush fruit. In particular, no research has been conducted on the bioactive content of European Cranberrybush fruits grown in similar ecologies in Turkey. In this research, it is aimed to compare some agro-morphological, biochemical and bioactive contents of the fruits of European Cranberrybush genotypes grown naturally in the Sivas province of Turkey.

\section{MATERIAL AND METHODS}

\section{Plant material}

In the study, 10 superior seedling genotypes of the European Cranberrybush (V. opulus L.) were determined by pre-selection (according to high yield and disease resistance characteristics), and their fruits were harvested at the end of October in 2013 and 2014 in the Sivas province of Turkey. The fruits of the genotypes were transferred to the laboratory via a cold chain and stored in plastic bags at $-24^{\circ} \mathrm{C}$ until analysis. The mesocarp part of the fruits was used in the analyses.

\section{Agro-morphological characteristics}

Fruit external colour, the number of fruits in a raceme, number of racemes per bush, and average fruit weight were determined. The number of fruits in a raceme was calculated using 20 racemes per bush in three replicates. The average weight of a fruit was measured by using an analytical balance with a sensitivity of $0.01 \mathrm{~g}$. The fruit external colour was determined by 5 panelists and classified as light red, red, or dark red.

\section{Biochemical characteristics}

Vitamin C, soluble solids content, titratable acidity and organic acids were determined as biochemical characteristics. The harvested fruits were juiced and a digital refractometer (ATAGO PR-32, Atago, Japan) was used to determine the soluble solids content (SSC). The juice was also used for vitamin $\mathrm{C}$ analysis. The vitamin $\mathrm{C}$ (ascorbic acid) content was measured by titration with 2,6-dichlorophenolindophenol sodium salt solution using chloroform for intensely coloured extracts (AOAC 1995). The titratable acidity (TA) 
was measured by titrating $10 \mathrm{~g}$ of fruit pulp that had been homogenized with $100 \mathrm{ml}$ distilled water. The initial $\mathrm{pH}$ of the sample was recorded before titration with $0.1 \mathrm{~N} \mathrm{NaOH}$ to a final $\mathrm{pH}$ of 8.2. The acidity was expressed as the percentage of citric acid equivalent to the quantity of $\mathrm{NaOH}$ used for the titration. Organic acid standards (citric, tartaric, oxalic, malic, succinic and fumaric) were obtained from Sigma-Aldrich (St. Louis, MO, USA). Organic acids of the fruits were identified by the modified method of Bevilacqua and Califano (1989). Juice extracts were obtained by mashing the fruits in a cheesecloth, after which the samples were stored at $\left(-24^{\circ} \mathrm{C}\right)$ until analyzed. $5 \mathrm{ml}$ of each sample was mixed with $20 \mathrm{ml}$ of $0.009 \mathrm{~N} \mathrm{H}_{2} \mathrm{SO}_{4}$ and then homogenized for $1 \mathrm{~h}$ with a shaker. The mixture was centrifuged for $15 \mathrm{~min}$. at 15,000 rpm, and the supernatants were filtrated twice with a $0.45 \mu \mathrm{m}$ membrane filter following filtration with a coarse filter (Millipore Millex-HV Hydrophilic PVDF, Millipore, USA), with the final passage through a SEP-PAK C18 cartridge. Organic acid readings were performed with HPLC using an Aminex column (HPX-87H, $300 \mathrm{~mm} \times 7.8 \mathrm{~mm}$, Bio-Rad Laboratories, Richmond, CA, USA) at 214 and 280 $\mathrm{nm}$ wavelengths, controlled by Agilent software (Agilent, USA).

\section{Bioactive content - sample preparation and extraction procedure}

The total phenolics, total anthocyanins, total flavonoids and total antioxidant capacity were analyzed in ripe fruit samples which had been stored at $-24^{\circ} \mathrm{C}$. After thawing, triplicates of $100 \mathrm{~g}$ of fruits from each genotype were homogenized in a blender and screened for bioactive content analysis (Singleton and Rossi 1965). In the extraction process, $3 \mathrm{~g}$ aliquots of each homogenate were used and transferred to test tubes. Twenty $\mathrm{ml}$ of extraction buffer consisting of acetone, deionized water and acetic acid (70:29.5:0.5 $\mathrm{v} / \mathrm{v} / \mathrm{v}$ ) were used for one hour. To determine total phenolics, Folin \& Ciocalteu's phenol reagent was used. For this purpose, a 1:1:20 (v/v/v) mixture of extract, reagent and water was incubated for eight minutes, followed by the addition of $10 \mathrm{ml}$ of $7 \%$ $(\mathrm{w} / \mathrm{v})$ sodium carbonate. The absorbance of each sample was measured at $750 \mathrm{~nm}$ after two hours. The total phenolics were estimated by comparing the absorbance of each sample with those of a standard response curve generated with gallic acid (Singleton and Rossi (1965). Results were expressed as mg gallic acid equivalents per $100 \mathrm{~g}$ on a fresh weight basis. Total anthocyanin content was determined by measuring the absorbance values at different $\mathrm{pH}$ values according to the method described by Wrolstad (1976). Absorbance was read against water in a spectrophotometer at 510 and $700 \mathrm{~nm}$, and calculated according to the $\mathrm{pH}$ absorbance value and expressed as mg cyanidin-3rutinoside per $100 \mathrm{~g}$. A colorimetric assay by Jia et al. (1999) was used for total flavonoid content. In a $10 \mathrm{ml}$ flask, $2 \mathrm{ml}$ of extracts were mixed with distilled water to reach a final volume of $5 \mathrm{ml}$. After that, $0.3 \mathrm{ml}$ of $0.72 \mathrm{~mol} \mathrm{l}^{-1} \mathrm{NaNO}_{2}$ was added at zero time to the flask. Then $0.6 \mathrm{ml}$ of $0.41 \mathrm{~mol} \mathrm{l}^{-1}$ $\mathrm{AlCl}_{3}$ was added after $5 \mathrm{~min}$., and $2 \mathrm{ml}$ of $1 \mathrm{~mol} \mathrm{l}^{-1}$ $\mathrm{NaOH}$ was added after 6 min., followed by $2.1 \mathrm{ml}$ of distilled water. Finally, absorbance at $510 \mathrm{~nm}$ was read against the blank (water), and the results were given as $\mu \mathrm{g}$ rutin equivalents per $100 \mathrm{~g}$ fresh weight.

FRAP (Ferric Reducing Antioxidant Power) assay was used for antioxidant capacity determination. To do this, $2.95 \mathrm{ml}$ aliquots of a FRAP reagent, a mixture of $0.1 \mathrm{~mol} \mathrm{l}^{-1}$ acetate buffer, $10 \mathrm{mmol} \mathrm{l}^{-1}$ TPTZ, and $20 \mathrm{mmol} \mathrm{l}^{-1}$ ferric chloride $(10: 1: 1, \mathrm{v} / \mathrm{v} / \mathrm{v})$, were combined with $50 \mu 1$ of acetone fruit extract. To determine the antioxidant capacity of the samples, the absorbance values were compared with those obtained from the standard curves of Trolox $\left(10-100 \mu \mathrm{mol} \mathrm{l}^{-1}\right)$. The antioxidant capacity values were expressed as $\mu \mathrm{mol}$ Trolox equivalents per $\mathrm{g}$ on a fresh weight basis (Benzie and Strain 1996).

\section{Statistical analysis}

All data were analyzed using SPSS software (SPSS Inc., Chicago, IL, USA). The experimental data were analyzed by one-way analysis of variance (ANOVA) with pairwise comparisons, followed by the least significant difference test (LSD). The results are presented as the mean \pm standard deviation (SD). The $p<0.05$ was considered statistically significant. There were no statistical differences between years, thus the data for both years were pooled.

\section{RESULTS AND DISCUSSION}

\section{Agro-morphological characteristics}

There were statistical differences in fruit weight, the number of fruit per raceme and the number of racemes per bush among the European Cranberrybush genotypes at the $p<0.05$ level (Tab. 1). The weight of fruits produced by the ten European Cranberrybush genotypes ranged from 0.67 to $0.82 \mathrm{~g}$. Fruits from the SIV-6 seedlings 
Table 1. Agro-morphological characteristics of European Cranberrybush genotypes (average for 2013-2014)

\begin{tabular}{llcccc}
\hline Genotype & $\begin{array}{c}\text { Fruit weight } \\
(\mathrm{g})\end{array}$ & $\begin{array}{c}\text { Fruit flesh ratio } \\
(\%)\end{array}$ & $\begin{array}{c}\text { Fruit skin } \\
\text { colour }\end{array}$ & $\begin{array}{c}\text { Number of fruit per } \\
\text { raceme }\end{array}$ & $\begin{array}{c}\text { Number of racemes } \\
\text { per bush }\end{array}$ \\
\hline SIV-1 & $0.70 \pm 0.06 \mathrm{ab}$ & $89.1^{\mathrm{NS}}$ & light red & $57.1 \pm 4.2 \mathrm{a}$ & $542 \pm 38 \mathrm{~b}$ \\
SIV-2 & $0.67 \pm 0.05 \mathrm{~b}$ & 93.2 & red & $43.8 \pm 3.8 \mathrm{bc}$ & $488 \pm 29 \mathrm{~cd}$ \\
SIV-3 & $0.75 \pm 0.05 \mathrm{ab}$ & 90.1 & light red & $52.4 \pm 5.7 \mathrm{ab}$ & $470 \pm 33 \mathrm{~d}$ \\
SIV-4 & $0.73 \pm 0.07 \mathrm{ab}$ & 90.7 & red & $40.7 \pm 3.6 \mathrm{c}$ & $502 \pm 35 \mathrm{c}$ \\
SIV-5 & $0.78 \pm 0.07 \mathrm{ab}$ & 91.4 & light red & $54.6 \pm 5.3 \mathrm{ab}$ & $581 \pm 41 \mathrm{a}$ \\
SIV-6 & $0.82 \pm 0.08 \mathrm{a}$ & 92.0 & light red & $46.8 \pm 4.9 \mathrm{~b}$ & $474 \pm 24 \mathrm{~d}$ \\
SIV-7 & $0.69 \pm 0.04 \mathrm{ab}$ & 92.8 & dark red & $42.1 \pm 4.0 \mathrm{c}$ & $521 \pm 31 \mathrm{bc}$ \\
SIV-8 & $0.80 \pm 0.07 \mathrm{ab}$ & 90.4 & dark red & $55.3 \pm 6.1 \mathrm{ab}$ & $538 \pm 29 \mathrm{~b}$ \\
SIV-9 & $0.70 \pm 0.06 \mathrm{ab}$ & 91.8 & dark red & $50.6 \pm 5.3 \mathrm{ab}$ & $567 \pm 33 \mathrm{ab}$ \\
SIV-10 & $0.74 \pm 0.05 \mathrm{ab}$ & 90.7 & dark red & $53.3 \pm 5.2 \mathrm{ab}$ & $481 \pm 27 \mathrm{~cd}$ \\
\hline
\end{tabular}

NS - non significant. Values in a column marked with the same letter do not differ significantly at $p<0.05$

showed higher fruit weight values than the rest of the genotypes, but the differences were not significant relative to the other seedlings. The lowest weight found was $0.67 \mathrm{~g}$ in the SIV-2 genotype, but it too was not significant relative to the other seedlings. Previously, the weight of European Cranberrybush fruit had been reported between 0.40 and $0.87 \mathrm{~g}$ (Bolat and Ozcan 1995, Kara et al. 1995, Kollmann and Grubb 2002, Karadeniz et al. 2003, Cesoniene et al. 2010, Ozrenk et al. 2011, Gundogar 2013). Large fruit is a desirable quality trait, primarily for the fresh fruits and secondly for the dried ones, rendering them more attractive to consumers. Besides, the relatively large size of European Cranberrybush fruits is also very important because it facilitates the harvesting of these small and delicate fruits.

The fruit flesh ratio varied between 89.1\% in SIV-1 and $93.2 \%$ in SIV-2 (Tab. 1), being in agreement with the findings of Gundogar (2013).

Among the 10 genotypes, 4 genotypes had a light red fruit skin colour, 4 genotypes were dark red and 2 genotypes were red in colour (Tab. 1). Ozrenk et al. (2011) had reported that European Cranberrybush genotypes in eastern Turkey generally had a dark red fruit skin colour. Gundogar (2013) selected 50 European Cranberrybush genotypes in Turkey and found that 12 genotypes had a light red fruit skin colour, 31 genotypes were red, and 7 genotypes had a dark red fruit skin colour. The red colour of European Cranberrybush fruits depends mostly on the accumulation of anthocyanins in them.

The number of fruit per raceme and the number of racemes per bush in the 10 European Cranberrybush genotypes were found between 40.7 and 57.1, and 470 and 581, respectively. Cesoniene et al. (2010) had reported a wide variation in 10 cultivars and genotypes of European Cranberrybush in Lithuania for the number of fruit per raceme and the number of racemes per bush as 29.6-78.6 (average 46.2) and 228-1039 (average 630), respectively. Ozrenk et al. (2011) reported the number of fruit per raceme between 29 and 71 in 2 genotypes of European Cranberrybush grown in eastern Turkey. Gundogar (2013) also reported values between 33 and 63 in a natural European Cranberrybush population in central Anatolia. Kara et al. (1995) and Karadeniz et al. (2003) had reported these values as 31 and 75 in the middle and northern parts of Turkey. The varied number of fruits per raceme in the European Cranberrybush is likely to be due to genetic background, fertilization and ecology (Gundogar 2013).

\section{Biochemical characteristics}

When Table 2 is examined, statistically significant differences $(p<0.05)$ can be seen between the genotypes in terms of vitamin $\mathrm{C}, \mathrm{SSC}$, and tartaric and malic acid contents. Vitamin $\mathrm{C}$ content of the European Cranberrybush genotypes ranged from 28 to $39 \mathrm{mg}$ per $100 \mathrm{~g}$. Ozrenk et al. (2011) had determined vitamin $\mathrm{C}$ in European Cranberrybush grown in two different provinces of eastern Anatolia between 32.76 and $33.43 \mathrm{mg}$ per $100 \mathrm{~g}$, indicating similarity to our present results. Cam and Hisil (2007) reported vitamin C at $35.20 \mathrm{mg}$ per $100 \mathrm{~g}$ of fruit in European Cranberrybush in Turkey. Cesoniene et al. (2010) reported a wide variation in vitamin $\mathrm{C}$ content of 10 cultivars and genotypes of European Cranberrybush in Lithuania, in the range 12.4-41.1 $\mathrm{mg}$ per $100 \mathrm{~g}$ of fruit (average $27 \mathrm{mg}$ ). Cam et al. (2007) reported an ascorbic acid concentration of $52.7 \mathrm{mg}$ per $100 \mathrm{~g}$ in $\mathrm{V}$. opulus fruit. In comparison with tabulated data for other 
Table 2. Vitamin C, soluble solids content (SSC), and organic acids in fruits of European Cranberrybush genotypes (average for 2013-2014)

\begin{tabular}{lcccccc}
\hline \multirow{2}{*}{ Genotype } & \multirow{2}{*}{$\begin{array}{c}\text { Vitamin C } \\
\text { (mg per 100 g FW) }\end{array}$} & SSC (\%) & \multicolumn{3}{c}{ Organic acids (mg per 100 g FW) } \\
\cline { 4 - 7 } SIV-1 & $33 \pm 2.9 \mathrm{ab}$ & $10.1 \pm 0.6 \mathrm{ab}$ & $124 \pm 12 \mathrm{ab}$ & $110 \pm 9 \mathrm{~d}$ & $13^{\mathrm{NS}}$ & $6.0^{\mathrm{NS}}$ \\
SIV-2 & $30 \pm 1.7 \mathrm{ab}$ & $11.1 \pm 0.5 \mathrm{ab}$ & $120 \pm 11 \mathrm{~b}$ & $133 \pm 11 \mathrm{a}$ & 15 & 5.1 \\
SIV-3 & $35 \pm 3.1 \mathrm{ab}$ & $9.8 \pm 0.5 \mathrm{~b}$ & $136 \pm 14 \mathrm{ab}$ & $124 \pm 12 \mathrm{c}$ & 10 & 5.0 \\
SIV-4 & $28 \pm 2.0 \mathrm{~b}$ & $11.7 \pm 0.7 \mathrm{ab}$ & $132 \pm 14 \mathrm{ab}$ & $117 \pm 9 \mathrm{~cd}$ & 16 & 4.8 \\
SIV-5 & $30 \pm 3.2 \mathrm{ab}$ & $11.3 \pm 0.6 \mathrm{ab}$ & $130 \pm 13 \mathrm{ab}$ & $130 \pm 12 \mathrm{ab}$ & 12 & 4.6 \\
SIV-6 & $29 \pm 2.5 \mathrm{ab}$ & $12.6 \pm 0.7 \mathrm{a}$ & $144 \pm 11 \mathrm{a}$ & $135 \pm 12 \mathrm{a}$ & 10 & 4.0 \\
SIV-7 & $33 \pm 3.0 \mathrm{ab}$ & $12.0 \pm 0.7 \mathrm{ab}$ & $120 \pm 10 \mathrm{~b}$ & $115 \pm 10 \mathrm{~cd}$ & 18 & 5.5 \\
SIV-8 & $27 \pm 2.8 \mathrm{~b}$ & $10.9 \pm 0.6 \mathrm{ab}$ & $140 \pm 11 \mathrm{a}$ & $120 \pm 9 \mathrm{~cd}$ & 17 & 4.3 \\
SIV-9 & $39 \pm 4.1 \mathrm{a}$ & $12.3 \pm 0.7 \mathrm{ab}$ & $132 \pm 11 \mathrm{ab}$ & $128 \pm 11 \mathrm{~b}$ & 16 & 5.9 \\
SIV-10 & $31 \pm 3.2 \mathrm{ab}$ & $11.4 \pm 0.5 \mathrm{ab}$ & $134 \pm 13 \mathrm{ab}$ & $130 \pm 11 \mathrm{ab}$ & 13 & 5.2 \\
\hline
\end{tabular}

Explanations: see Table 1

fruit species this value is moderately higher than for blackberry (Rubus fruticosus) - 15.5-16.3 mg per $100 \mathrm{~g}$ (Benvenuti et al. 2004) and American cranberry (Vaccinium macrocarpon Aiton) - 11.8$15.8 \mathrm{mg}$ per $100 \mathrm{~g}$ (Viskelis et al. 2009). However, it does not reach the values which are observed in, for example, blackcurrant (Ribes nigrum) - 150.3$275.8 \mathrm{mg}$ per $100 \mathrm{~g}$ (Viskelis et al. 2008). Vitamin C (ascorbic acid) is an important nutrient for humans and has many functions.

Small, but statistically significant $(p<0.05)$, differences in SSC values were detected among the genotypes of $V$. opulus, ranging from 9.8 to $12.6 \%$ (Tab. 2). The levels of SSC, especially in relation to acidity are important components of quality of several fruits, jams and juices (Zhao et al. 2015). Considerably lower levels of SSC in genotypes suggest that they are more suitable for processed products, such as jams or mixed juices. Interestingly, SSC values similar to the present ones were reported in other studies of $V$. opulus in Turkey (Bolat and Ozcan 1995, Kara et al. 1995, Karadeniz et al. 2003, Ozrenk et al. 2011, Gundogar 2013), indicating that the cultivation in different parts of Turkey plays a minor role in the levels of these important fruit characteristics.

In this study, significant differences were detected in the accumulation of organic acids by the different European Cranberrybush genotypes (Tab. 2 ), although the results are in general agreement with the findings of other studies (Ozrenk et al. 2011). The SIV-6 genotype of $V$. opulus accumulated high levels of tartaric and malic acids, averaging $144 \mathrm{mg}$ per $100 \mathrm{~g}$ and $135 \mathrm{mg}$ per $100 \mathrm{~g}$, respectively, while SIV-2 (120 mg per $100 \mathrm{~g})$ and SIV-1 (110 mg per $100 \mathrm{~g}$ ) had the lowest tartaric and malic acid contents, but the differences were not significant relative to the other genotypes. Ozrenk et al. (2011) had reported that fluctuations in the levels of organic acids did exist among different genotypes of $V$. opulus.

\section{Bioactive content}

The fruits of the SIV-7 genotype contained significantly higher levels of total phenolics than all the other genotypes of $V$. opulus (Tab. 3), reaching $987 \mathrm{mg}$ GAE per $100 \mathrm{~g} \mathrm{FW}$, with the SIV-3 genotype having the lowest total phenolic content of $621 \mathrm{mg}$ GAE per $100 \mathrm{~g} \mathrm{FW}$. Medium values of total phenols were observed in all the other genotypes. Polyphenols have been proven to have beneficial antioxidant, anti-microbial and anti-inflammatory properties, and fruits of the European Cranberrybush are considered to be good sources of both. Kraujalyte et al. (2013) had studied the polyphenolic content of $V$. opulus genotypes and, in agreement with the results of this study, found significant differences between the studied genotypes (from 540 to $1060 \mathrm{mg}$ per $100 \mathrm{~g} \mathrm{FW}$ ). Cam and Hisil (2007) reported that TPC in $V$. opulus was in the range of $330-350 \mathrm{mg}$ per $100 \mathrm{ml}$ of juice, which is markedly lower than in the juice analyzed in our work. Cesoniene et al. (2010) reported total phenolic content in extracts from the fruits of $V$. opulus between 753 and $1280 \mathrm{mg}$ GAE per $100 \mathrm{~g} \mathrm{FW}$ and indicated that the differences in total phenolic amounts expressed as GAE were caused by genetic variation. The Total Phenolic Content (TPH) of fresh V. opulus fruit had previously been reported to be 351.3-356.6 mg per $100 \mathrm{~g}$ (Cam et al. 2007, Cam and Hisil 2007), which was lower than in our study. Cranberries contain about $315 \mathrm{mg}$ TPH per $100 \mathrm{~g}$ (Zheng and Wang 2003). Ozdal et 
Table 3. Bioactive contents of European Cranberrybush fruits (average for 2013-2014)

\begin{tabular}{lcccc}
\hline Genotype & $\begin{array}{c}\text { Total phenolics } \\
\text { (mg GAE per 100 g FW) }\end{array}$ & $\begin{array}{c}\text { Total flavonoids } \\
\text { (mg rutin equiv } \\
\text { per 100 g FW) }\end{array}$ & $\begin{array}{c}\text { Total anthocyanins } \\
\text { (mg cyanidin-3-rutinoside } \\
\text { equiv per 100 g) }\end{array}$ & $\begin{array}{c}\text { FRAP } \\
(\mu \text { mol Trolox equiv per g) }\end{array}$ \\
\hline SIV-1 & $740 \pm 23 \mathrm{bc}$ & $202 \pm 12 \mathrm{ab}$ & $15 \pm 1 \mathrm{e}$ & $25.32 \pm 3.1 \mathrm{ab}$ \\
SIV-2 & $668 \pm 17 \mathrm{bc}$ & $234 \pm 14 \mathrm{ab}$ & $38 \pm 4 \mathrm{bc}$ & $30.47 \pm 4.2 \mathrm{ab}$ \\
SIV-3 & $621 \pm 15 \mathrm{c}$ & $211 \pm 10 \mathrm{~b}$ & $29 \pm 4 \mathrm{~cd}$ & $28.80 \pm 3.5 \mathrm{ab}$ \\
SIV-4 & $840 \pm 25 \mathrm{~b}$ & $265 \pm 14 \mathrm{ab}$ & $33 \pm 4 \mathrm{c}$ & $26.54 \pm 3.2 \mathrm{ab}$ \\
SIV-5 & $707 \pm 20 \mathrm{bc}$ & $258 \pm 11 \mathrm{ab}$ & $19 \pm 2 \mathrm{de}$ & $21.02 \pm 2.6 \mathrm{~b}$ \\
SIV-6 & $902 \pm 29 \mathrm{ab}$ & $305 \pm 17 \mathrm{ab}$ & $23 \pm 2 \mathrm{~d}$ & $27.20 \pm 2.9 \mathrm{ab}$ \\
SIV-7 & $987 \pm 32 \mathrm{a}$ & $318 \pm 16 \mathrm{a}$ & $51 \pm 5 \mathrm{a}$ & $33.68 \pm 4.7 \mathrm{ab}$ \\
SIV-8 & $887 \pm 27 \mathrm{ab}$ & $286 \pm 15 \mathrm{ab}$ & $45 \pm 4 \mathrm{ab}$ & $31.47 \pm 4.3 \mathrm{ab}$ \\
SIV-9 & $795 \pm 23 \mathrm{bc}$ & $297 \pm 15 \mathrm{ab}$ & $42 \pm 4 \mathrm{~b}$ & $29.13 \pm 3.4 \mathrm{ab}$ \\
SIV-10 & $945 \pm 30 \mathrm{ab}$ & $275 \pm 13 \mathrm{ab}$ & $48 \pm 5 \mathrm{ab}$ & $34.90 \pm 4.5 \mathrm{a}$ \\
\hline
\end{tabular}

Values in a column marked with the same letter do not differ significantly at $p<0.05$

al. (2014) reported that the total phenolic content of 10 European Cranberrybush genotypes in the Kayseri province of Turkey varied in the range of 549-917 mg gallic acid equivalents per $100 \mathrm{~g} \mathrm{FW}$. Phenolic compounds have a permeability regulator and blood pressure lowering effect in the capillary circulatory system, as well as an antioxidant effect (Mojzer et al. 2016).

Total flavonoid content was found between 202 (SIV-1) and 318 (SIV-7) mg rutin equivalents per 100 g FW (Tab. 3), indicating significant statistical differences among $V$. opulus genotypes. It seems that the genotype strongly influences the accumulation of flavonoids in European Cranberrybushes. Rop et al. (2010) determined the total flavonoid content in fresh fruits of $V$. opulus to be 314-489 mg per $100 \mathrm{~g}$, indicating higher values than in our study. Flavonoid compounds with antioxidant properties reduce inflammation, form healthy blood vessels, prevent cell damage and delay ageing (Kahraman et al. 2002).

The amounts of total anthocyanins in $V$. opulus fruits expressed as cyanidin 3-glucoside ranged from 15 to $51 \mathrm{mg}$ per $100 \mathrm{~g}$ (Tab. 3). Cesoniene et al. (2010) had reported total anthocyanin content between 23.2 and $44.6 \mathrm{mg}$ per $100 \mathrm{~g}$ in Lithuania. Previous studies had reported a variation in the TAC of $V$. opulus fruits between 22.9 and $49.9 \mathrm{mg}$ per $100 \mathrm{~g}$ (Benvenuti et al. 2004), and between 22 and $29 \mathrm{mg} 100 \mathrm{~g}$ (Deineka et al. 2005), which is in agreement with our results. Anthocyanins prevent cell ageing. They protect healthy tissues and cells, and thus reduce the risk of cancer and heart disease (Delgado-Vargas and PakirmiziesLopez 2003).
In the present study, the total antioxidant capacity values were found between 21.02 (SIV-5) and 34.90 (SIV-10) expressed as $\mu$ mol Trolox per $\mathrm{g}$ in the FRAP method. The highest antioxidant capacity was in the SIV-10 genotype, reaching 34.90 $\mu$ mol Trolox per g, but the differences relative to the other genotypes were not significant. A statistically significant difference was only between SIV-10 and SIV-5 (Tab. 3). It appears that the SIV-10 genotype synthesizes/accumulates higher levels of total phenolics and other antioxidants in its organs than the rest of the genotypes. Kraujalyte et al. (2013) had found the iron-ion-reducing antioxidant power values in the fruits of six different $V$. opulus varieties to be 32.3-61.8 $\mu \mathrm{mol}$ Trolox equivalents per g. Ozdal et al. (2014) reported that antioxidant capacity is highly variable among European Cranberrybush genotypes grown in central Anatolia. To the best of our knowledge, the antioxidant activity of $V$. opulus fruit had not previously been evaluated by the FRAP assay in Turkey and there were very few results on this characteristic in the literature.

\section{CONCLUSIONS}

The results revealed that, in Turkey, there was variation in terms of fruit agro-morphological, biochemical and bioactive characteristics among seed propagated $V$. opulus genotypes sampled in the Sivas province (central Anatolia), indicating the importance of selecting the best genotypes for future cross-breeding activities. This also highlights that fruits of the European Cranberrybush genetic resources in Turkey could be used for special breeding purposes to obtain new European 
Cranberrybush genotypes that would produce fruit with more human health enhancing contents.

\section{AUTHOR CONTRIBUTIONS}

N.E., S.E. and M.G. - equally contributed to the experimental design, analytical measurements, statistical analysis and manuscript writing.

\section{CONFLICT OF INTEREST}

Authors declare no conflict of interest.

\section{REFERENCES}

Altun M.L., Citoglu G.S., Yilmaz B.S., Coban T., 2008. Antioxidant properties of Viburnum opulus and Viburnum lantana growing in Turkey. Int. J. Food Sci. Nutr. 59(3): 175-180.

AOAC., 1995. Official Methods of Analysis (16th edn). AOAC International, Arlington, VA: 16-17.

Bae K., Chong H., Kim D., Choi Y.W., Kim Y.S., Kim Y.K., 2010. Compounds from Viburnum sargentii Koehne and evaluation of their cytotoxic effects on human cancer celllines. Molecules 15(7): 4599-4609.

Bevilacqua A.E, Califano A.N., 1989. Determination of organic acids in dairy products by high performance liquid chromatography. J. Food Sci. 54: 1076-1079.

Benvenuti S., Pellati F., Melegari M., Bertelli D., 2004. Polyphenols, anthocyanins, ascorbic acid, and radical scavenging activity of Rubus, Ribes, and Aronia. J. Food Sci. 69: FCT164-FCT169.

Benzie I.F.F., Strain J.J., 1996. The ferric reducing ability of plasma (FRAP) as a measure of 'antioxidant power': The FRAP assay. Anal. Biochem. 239: 70-76.

Bharucha Z., Pretty J., 2010. The roles and values of wild foods in agricultural systems. Philos. Trans. R. Lond. B Biol. Sci. 365: 2913-2926.

Bolat S., OzCan M., 1995. The morphological, phenological and chemical composition of cranberry tree (Viburnum opulus L.) fruits. Proc. $2^{\text {nd }}$ National Horticultural Congress, Cukurova University Agricultural Faculty, Adana, Turkey: 772-775.

CAM M., Hisil Y., 2007. Comparison of chemical characteristics of fresh and pasteurised juice of gilaburu (Viburnum opulus L.). Acta Aliment. 36: 381-385.

Cam M., Hisil Y., Kuscu A., 2007. Organic acid, phenolic content and antioxidant capacity of fruit flesh and seed of Viburnum opulus. Chem. Nat. Comp. 43: 460-461.

Canan I., Gundogdu M., Seday U., Oluk C.A., Karasahin Z., Eroglu E.C., Yazici E., Unlu M., 2016. Determination of antioxidant, total phenolic, total carotenoid, lycopene, ascorbic acid, and sugar contents of Citrus species and mandarin hybrids. Turk. J. Agric. For. 40: 894-899.
Cesoniene L., Daubaras R., 2006. Diversity of yielding capacity and biochemical composition of European cranberry bush (Viburnum opulus) genetic resources. Scripta Horti Botanici Universitatis Vytauti Magni 11: 19-28.

Cesonienee L., Daubaras R., Viskelis P., 2008. Evaluation of productivity and biochemical components in fruit of different Viburnum accessions. Biologia 54: 93-96.

Cesoniene L., Daubaras R., Vencloviene J., Viskelis P., 2010. Biochemical and a gro-biological diversity of Viburnum opulus genotypes. Cent. Eur. J. Biol. 6: 864-871.

Dansi A., Adjatin A., Adoukonou-Sagbadja H., Falade V., Ydomonhan H., Odou D., Dossou B., 2008. Traditional leafy vegetables and their use in the Benin Republic. Genet. Resour. Crop Evol. 55: 1239-1256.

DeineKa V.I., Sorokopudov V.N., Deineka L.A., Shaposhnik E.I., Kol'Tsov S.V., 2005. Anthocyanins from fruit of some plants of the Caprifoliaceae family. Chem. Nat. Comp. 41: 162-164.

Delgado-Vargas F., Pakirmizies-LóPez O., 2003. Natural Colorants for Food and Nutraceutical Uses. CRC Press, Boca Raton, FL, USA.

Ercisli S., Tosun M., Duralija B., Voca S., Sengul M., Turan M., 2010. Phytochemical content of some black (Morus nigra L.) and purple (Morus rubra L.) mulberry genotypes. Food Technol. Biotechnol. 48(1): 102-106.

Fukuyama Y., Minoshima Y., Kishimoto Y., Chen I.S., Takahashi H., Esumi T., 2005. Cytotoxic iridoid aldehydes from Taiwanese Viburnum luzonicum. Chem. Pharm. Bull. 53: 125-127.

Gundogar R., 2013. Determination of wild quelder rose (Viburnum opulus L.) genotypes grown in Kayseri province. PhD thesis, University of Ordu, Institute for Graduate Studies in Science and Technology, Turkey, $61 \mathrm{p}$.

Iwai K., OnOdera A., Matsue H., 2004. Inhibitory effects of Viburnum dilatatum Thunb. (gamazumi) on oxidation and hyperglycemia in rats with streptozocin-induced diabetes. J. Agric. Food Chem. 52: 1002-1007.

JiA Z.S., TANG M.C., WU J.M., 1999. The determination of flavonoid contents in mulberry and their scavenging effects on superoxide radicals. Food Chem. 64: 555-559.

Kahraman A., Serteser M., Koken T., 2002. Flavonoids. Med. J. Kocatepe 3: 1-8.

Kalyoncu I.H., Ersoy N., Elidemir A.Y. Karali M.E., 2013. Some physico-chemical characteristics and mineral contents of gilaburu (Viburnum opulus L.) fruits in Turkey. Int. J. Biol. Vet. Agric. Food Eng. 7(6): 169-171.

Kara Z., Fidan Y., Gercekcioglu R., 1995. A study, phenological and pomological characteristics of $V$. opulus L. genotypes grown in Tokat province in 
Turkey. Proc. $2^{\text {nd }}$ National Horticultural Congress: 767-771.

Karadeniz T., Sisman T., Sen S.M., 2003. Morphological and pomological characteristics of Viburnum opulus L. genotype. Proc. National Kiwifruit and Berry Fruit Symposium: 481-484.

Kim M.Y., IwaI K., Matsue H., 2005. Phenolic composition of Viburnum dilatatum Thumb. fruits and their antiradical properties. J. Food Comp. Anal. 18: 789-802.

Kollmann J., GrubB P.J., 2002. Viburnum lantana L. and Viburnum opulus L. (V. lobatum Lam., Opulus vulgaris Borkh.). J. Ecol. 90: 1044-1070.

Kraujalyte V., Venskutonis P.R., Pukalskas A., Cesoniene L., Daubaras R., 2013. Antioxidant properties and polyphenolic compositions of fruits from different European cranberrybush (Viburnum opulus L.) genotypes. Food Chem. 141(4): 36953702.

Lavigne J.P., Bourg G., Combescure C., Botto H., Sotтo A., 2008. In-vitro and in-vivo evidence of dose-dependent decrease of uropathogenic Escherichia coli virulence after consumption of commercial Vaccinium macrocarpon (cranberry) capsules. Clin. Microbiol. Infect. 14(4): 350-355.

Mahapatra A.K., Albers H.J., Robinson E.J.Z., 2005. The impact of NTFP sales on rural households' cash income in India's dry deciduous forest. Environ. Manage. 35: 258-265.

Mikulic-Petkovsek M., Schmitzer V., Slatnar A., Stampar F., Veberic R., 2012. Composition of sugars, organic acids, and total phenolics in 25 wild or cultivated berry species. J. Food Sci. 77: C1064-C1070.

Mikulic-Petkovsek M., Schmitzer V., Slatnar A., Todorovic B., Veberic R., Stampar F., Ivancic A., 2014. Investigation of anthocyanin profile of four elderberry species and interspecific hybrids. J. Agric. Food Chem. 62: 5573-5380.

Mikulic-Petkovsek M., Ivancic A., Todorovic B., Veberic R., Stampar F., 2015. Fruit phenolic composition of different elderberry species and hybrids. J. Food Sci. 80: C2180-2190.

Mikulic-Petkovsek M., Krska B., Kiprovski B., Veberic R., 2017. Bioactive components and antioxidant capacity of fruits from nine sorbus genotypes. J. Food Sci. 82: 647-658.

Mojzer B., Hrncic M.K., Skerget M., Knez Z., BREN U., 2016. Polyphenols: extraction methods, antioxidative action, bioavailability and anticarcinogenic effects. Molecules 21: 901.

Ozdal T., Esen O.B., Dogan G., Capanoglu E., BoyaCIOGLU E., 2014. Investigating the antioxidant capacities of Viburnum opulus L. fruits cultivated in Kayseri, Turkey. $2^{\text {nd }}$ Int. Congress on Food Technology, 5-7 November, Kuşadası, Turkey.
Ozrenk K., Gundogdu M., Keskin N., Kaya K., 2011. Some physical and chemical characteristics of gilaburu (Viburnm opulus L.) fruits in Erzincan region. J. Inst. Sci. Technol. 1(4): 9-14.

Rop O., Reznicek V., Valsikova M., Jurikova T., MlceK J., Kramarova D., 2010. Antioxidant properties of European cranberrybush fruit (Viburnum opulus var. Edule). Molecules 15: $4467-$ 4477.

Rop O., Ercisli S., MlceK J., Jurikova T., Hoza I., 2014. Antioxidant and radical scavenging activities in fruits of 6 sea buckthorn (Hippophae rhamnoides L.) cultivars. Turk. J. Agric. For. 38(2): 224-232.

SARIDAS M.A., KafKas N.E., ZarifiKhosroshahi M., Bozhaydar O., Kargi S.P., 2016. Quality traits of green plums (Prunus cerasifera Ehrh.) at different maturity stages. Turk. J. Agric. For. 40: 655-663.

Singh J.S., Raghubanshi A.S., Varshney C.K., 1994. Integrated biodiversity research in India. Curr. Sci. 66: 109-112.

SingLeton V.L., Rossi J.L., 1965. Colorimetry of total phenolics with phosphomolybdic-phosphotungstic acid reagents. Am. J. Enol. Vitic. 16: 144-158.

Viskelis P., Rubinskienee M., Bobinas C., 2008. Evaluation of strawberry and black currant berries intended for freezing and the methods of their preparation. J. Food Agric. Environ. 6: 151-154.

Viskelis P., Rubinskiene M., Jasutiene I., SARkinas A., Daubaras R., Cesoniene L., 2009. Anthocyanins, antioxidative, and antimicrobial properties of American cranberry (Vaccinium macrocarpon Ait.) and their press cakes. J. Food Sci. 74: C157-C161.

Wrolstad R.E., 1976. Color and pigment analysis in fruit products. Agricultural Station Bulletin 624, Oregon State University, USA.

YAZICI K., SAHIN A., 2016. Characterization of pomegranate (Punica granatum L.) hybrids and their potential use in further breeding. Turk. J. Agric. For. 40: 813-824.

Zheng W., WANG S.Y., 2003. Oxygen radical absorbing capacity of phenolics in blueberries, cranberries, chokeberries, and lingonberries, J. Agric. Food Chem. 51: 502-509.

Zhao J., Haoxia L., Wanpeng X., Wei A., Linlin N., Youlong C., Huafang W., Yauun W., Yue Y., 2015. Changes in sugars and organic acids in wolfberry (Lycium barbarum L.) fruit during development and maturation. Food Chem. 173: 718-724.

Zorenc Z., Veberic R., Stampar F., Koron D., Mikulic-Petkovsek M., 2016. Changes in berry quality of northern highbush blueberry (Vaccinium corymbosum L.) during the harvest season. Turk. J. Agric. For. 40: 855-867.

Received June 28, 2017; accepted September 4, 2017 